\title{
Los poemas inéditos de Changó, el gran putas: el papel del poeta, las armas y las letras*
}

\author{
John Maddox ${ }^{1}$ \\ Universidad de Alabama en Birmingham
}

ORCID:0000-0002-8309-2363

Recibido: 25 de noviembre de 2019

Aceptado: 20 de febrero de 2020

\begin{abstract}
RESUMEN
Una lectura comparativa de los poemas inéditos de los Manuel Zapata Olivella Papers (los Papeles de Manuel Zapata Olivella en Vanderbilt University, Estados Unidos) con los que aparecen en la versión definitiva de Changó, el gran putas (1983) muestra una reestructuración del texto, en el que detalles importantes revelan la posición del autor en cuanto a que las letras cuentan tanto como las armas en el recuerdo y la liberación de la diáspora africana. Este artículo focalizará su análisis en distintas manifestaciones del rol del poeta en la sociedad: el guerrero-poeta Nagó el Navegante, los orichas Elegua y Oko y el griot Ngafúa/Bandama. La poesía en la novela representa, en cada caso, una forma distinta de arma libertadora.
\end{abstract}

Palabras clave: Manuel Zapata Olivella, Afro-Colombia, poesía, religiones sincréticas

\begin{abstract}
A comparative reading of the unpublished poems from the Manuel Zapata Olivella Papers (Vanderbilt University, United States) with those that appear in the definitive version of Changó, the Biggest Baddass (1983) shows the restructuring of the text in which important details reveal the author's position that works count as much as weapons in the recollection and liberation of the African Diaspora. The focus of analysis will be different manifestations of the role of the poet in society: the warrior-poet Nagó the Navigator, the orichas Elegua and Oko, and the griot Ngafúa/ Bandama. Poetry in the novel presents, in each case, a different kind of liberating weapon.
\end{abstract}

Keywords: Manuel Zapata Olivella, Afro-Colombia, poetry, syncretic religions

\section{INTRODUCCIÓN}

Changó, el gran putas (1983) es la obra maestra del afrocolombiano Manuel Zapata Olivella y una de las obras más complejas e importantes del siglo XX. Narra la historia de la diáspora africana

\footnotetext{
* The Unpublished Poems of Changó the Biggest Baddass: The Role of the Poet, Arms, and Letters

${ }^{1}$ Profesor Asistente de Español y Estudios Afroamericanos, Universidad de Alabama en Birmingham, Estados Unidos. Ph.D. en Español y Portugués por la Universidad de Vanderbilt. Correo:jtmaddox@uab.edu.
} 
desde sus orígenes en la costa occidental de África hasta las luchas por los derechos de los negros norteamericanos en los años sesenta, abarcando la historia de la diáspora en América. El siguiente ensayo compara los poemas inéditos que se encuentran en Vanderbilt University, Nashville, Tennessee, con la versión final de la novela publicada por la Biblioteca Afrocolombiana (2010). ¿Cómo iluminan el texto final de la novela estos poemas recientemente descubiertos? Para responder a esta pregunta, primero presentaré a Nagó, el guerrero-poeta de los textos de Vanderbilt, yuxtaponiéndolo con los fundadores sangrientos de la Conquista y su propia versión final. Luego, muestro cómo el oricha Elegua otorga a Nagó, en las obras descubiertas, los elementos de la sinestesia y la paradoja para fortalecerlo. Analizo las armas de Nagó y su poética en ambas versiones de su historia. Noto que el oricha de la fertilidad, Oko, tiene más importancia en los textos de Tennessee que en la novela. Concluyo con una hipótesis de por qué el afrocolombiano optó por cambiar el nombre de su poeta-narrador principal de Bandama a Ngafúa. En manos de Zapata Olivella, las palabras se convierten en armas anticoloniales, pero los detalles muestran la evolución de su estética.

\section{Estudios sobre la poética zapataolivellista}

En la versión publicada de Changó, Nagó es un líder guerrero. Muestra fuerza, valentía y lealtad a los dioses africanos. Su nombre y su contexto explican por sí mismos su función en el texto. Es el doble de Henrique el Navegante (1394-1460), el rey portugués que comenzó la trata negrera entre Portugal y África y, poco después, entre estos y el Nuevo Mundo. Aunque la esclavitud ha existido desde la antigüedad, la esclavización de africanos por europeos, justificada por su raza o supuesta impureza religiosa (no ser cristianos "de sangre") comienza con los portugueses. Volver a interpretar el origen de la trata negrera es la oportunidad de reevaluarla de manera radical.

Sin embargo, bajo el liderazgo de Nagó el Navegante, los negros rechazan el cristianismo de sus captores y optan por las armas para liberarse. Los cautivos, ancestros de los personajes de los siglos XVIII, XIX y XX en la novela, se rebelan:

Olugbala ya tiene sus muñecas fuera de las argollas y a mi lado, Kanuri mai empuñaba la lima con la mano suelta. Bajan alumbrándose con lámparas, repitiendo una letanía de difuntos que se alarga al descender por la escalera. Pero desde mucho antes escuchamos el repicar de una campanilla, el mismo con que nuestros babalaos invocan a Legba: ‘ $i V a-$ deretrosatán! ¡Vaderetrosatán.!'” (2010: 132)

Claramente, tanto los orichas como los ancestros deificados sirven de inspiración para la rebelión contra la opresión colonial. Legba representa a los dioses y Olugbala y Kanuri mai se convierten en ancestros espirituales al morir durante el motín. El grito de Nagó es la fundación de un nuevo mundo que corre paralelo a los hechos de la historia contada por los historiadores eurocéntricos.

La lucha de Nagó evoca la tradición épica, lo que reafirma la importancia de la poesía en la obra de Zapata Olivella. Las hazañas del héroe épico en altamar lo ponen a la altura de Ulises en $L a$ 
Odisea, como afirma William Mina Aragón (2006: 30). También está al nivel de Vasco da Gama en Os Lusíadas (1572) de Luís de Camões, el supuesto heredero de Homero, como afirma Julia Cuervo-Hewitt (2003). Varios otros estudiosos han tratado Changó como epopeya, entre ellos Cristina Cabral (2001), Haakayoo Zoggyie (2001), César Valencia Solanilla (2003), Sergio Andrés Sandoval (2015) y Elizabeth Santafé Valcárcel (2017). Ninguno de ellos propone al texto como un arte poética.

Tampoco debemos olvidar la importancia de tres poemas que aparecieron en el primer número de la revista Afro-Hispanic Review (1982), un año antes de la publicación de Changó, como muestra de una novela de más de 700 páginas que en aquel entonces todavía se llamaba Epopeya del Muntu Caminante (16). Sin embargo, ninguno de ellos fue incluido en la versión final de la novela: "El código guerrero" - que refiere a la unión, la violencia subversiva y la creatividad e inicia en el barco negrero-, "Navego" y "Visión: La travesía" ya proponen una visión de rebeldía negra. Según "El código", el premio de los seguidores de Changó es que "no habrá cadena que sujete tu brazo / cárcel que sepulte tu grito / espada que corte tu lengua" (s/p.). Propongo que veamos estos textos cortos como síntesis de los temas de la novela: la esclavitud, la rebeldía y la autodeterminación de la diáspora. El nombre "Nagó" es sinónimo de "yoruba", uno de los grupos principales que fue llevado al Caribe y a Brasil. El navegante es un africano esclavizado que se rebela, determina su propio destino y lidera el futuro de la diáspora aun después de su muerte. El escenario del mar es un elemento esencial para Nagó el Navegante y las implicaciones de su heroísmo, porque capitanea la Nova India, nave que va juntando las almas africanas perdidas en el mar debido a la esclavitud: “[...] abordamos los galeones negreros para librar a los difuntos. Allí en el mismo lugar donde agonizaron, Nagó les ayuda a desatar la soga y con ellos al hombro los trasborda a nuestro barco" (2010: 151-52). Mientras los barcos de Henrique el Navegante esclavizaron, el de Nagó libera. La fuerza vital de los fallecidos fortalece al Muntu, la humanidad, en el nuevo mundo en su lucha por la justicia. Claramente, las armas importan para Zapata Olivella, como es evidente en la violencia del motín.

No obstante, las letras también importan, sobre todo para formar y revisar cómo recordamos la historia. Todavía nos cuesta ver a Zapata Olivella como poeta porque logró su reconocimiento como novelista (Yvonne Captain-Hidalgo, 1993). El autor mismo dijo que nunca se imaginó como poeta hasta que tuvo una epifanía en África (Zapata Olivella, 2001a: 22). Fue inspirado por espíritus de africanos esclavizados durante una visita a la isla de Gorée en Senegal. Entonces, supuestamente escribió cuarenta poemas (Zapata Olivella, 2001a: 22). Dice que escogió doce para "Los orígenes" (22). Es más, refiere a los poemas como "épico africano" (22) y los presenta como un mensaje divino de parte de Changó por medio de Legba (Elegua) (22). Es decir, en vez de presentarse como autor occidental, se expresa como si fuera griot o hasta un poseído africano en la tradición de los yorubas. La epopeya señala el futuro de la diáspora africana, y el autor afirma que su visita a las cárceles de esclavos en la isla senegalesa de Gorée y la composición de los textos ocurre en 1976 (22). Sin embargo, la visita probablemente ocurrió en 1974 durante su participación 
en el "Coloquio Negritud y América Latina", el que se celebró en Dakar. El gran poeta de la negritud Léopold Sédar Senghor, presidente de Senegal y protagonista de la conferencia, permitió que su amigo Zapata Olivella pasara la noche con las almas de los ancestros, según la versión del colombiano. ¿Dónde estarán esos cuarenta poemas?

Es probable que estén en Nashville, Tennessee, en la Biblioteca Heard de Vanderbilt University. Como mínimo, los archivos acaban con cualquier duda sobre la importancia de la poesía en Changó. William Luis (2010: xi) y yo fuimos los primeros investigadores que vieron estos archivos en 2010, justo después de su llegada a la Heard Library a manos de Pablo Gómez (2011). No puedo dar mucha información a ciencia cierta sobre estos poemas, su contexto o por qué muchos no fueron incluidos en el manuscrito final del libro. No había orden ni pistas sobre sus orígenes en las cajas, las que recién habían llegado de la casa de Edelma Zapata Pérez, hija del autor (Gómez 2011: 117). Los textos tienen números y forman unidades semánticas con títulos - o sea, son poemas descriptivos y narrativos en serie. Quizá los números correspondan a números de páginas de un borrador de la novela, ya que hay encabalgamiento entre una sección numerada y otra. Es probable que Zapata Olivella estuviera haciendo revisiones en estos papeles, ya que hay cambios hechos a mano y versiones actualizadas engrapadas encima de versiones previas. Hay múltiples versiones de varios textos escritas a máquina y casi todas con revisiones manuales. El número total de poemas o páginas numerados que transcribí de los archivos es de $217 .{ }^{2}$ Comienzan con el subtítulo "Deja que cante la kora", aludiendo al arpa africana, análoga a la lira griega y símbolo de la poesía. Este principio corresponde a la página 41 de la versión de 2010 de la novela, basada en la primera edición de 1983. Por otro lado, la serie termina con "Bienvenida a Elegua abridor de puertas", lo que corresponde, en términos generales, a la página 76 (de las 81 páginas de "La tierra de los ancestros") porque aluden al descenso del semidios del baobab sagrado. Dicho eso, hay poca conexión u orden cronológico o narrativo entre las unidades semánticas.

Aunque las pistas textuales son pocas sobre su contexto original, podemos llegar a varias conclusiones usando estos documentos, como por ejemplo el aspecto formal de los poemas, compartido con los de la novela. Su forma es de verso libre y sus estrofas se dividen en versos de variable cantidad y extensión, principalmente de verso menor. Así, imita el canto oral de los yorubas, que no tiene número fijo de versos como el soneto occidental, por ejemplo (Santos, 2016: 41). El crítico Denilson Lima Santos ha estudiado la poética de Zapata Olivella en Changó y afirma que la variación de versificación es típica de los orikíes, poemas ceremoniales yorubas (2016: 29). Los orikíes son "evocaciones de las características de los orichas" o dioses africanos (2016: 32). Santos nota que, al leer (y no oír) estos versos, el lector pierde no solo la música del canto sino también el aspecto tonal de las lenguas yoruba y bantú (36). Por eso, en la interpretación de Santos, técnicas occidentales como la sinestesia, entre otras, sustituyen los elementos orales africanos en estos poemas. La forma orikiesca de los poemas es radical y también lo es su fondo.

\footnotetext{
2 "El Muntú en América", uno de los poemas que está en Vanderbilt, apareció en las revistas Afro-Hispanic Review (2001) y Guaraguao (2005). Según Michael Janis, Zapata desarrolla su teoría del mestizaje cultural americano en el poema corto. Los 23 poemas o fragmentos numerados que escogí para analizar en este ensayo estarán en la sección Fabulario de esta misma revista.
} 


\title{
2. Nagó: navegante, guerrero y poeta en los poemas hallados en Vanderbilt
}

Claramente, en la versión final de la novela, Nagó es guerrero. En la epopeya documentada en las fuentes de Vanderbilt también lo es, pero hay descripción de su armadura que simboliza África, evocando la supervivencia y rebeldía de su cultura sin olvidar la tradición guerrera. En los papeles de la biblioteca Heard, estas descripciones forman parte de una épica coherente compuesta en verso. En la versión publicada de la novela (1983, 2010), los siguientes versos solo aparecen en el contexto de las negociaciones entre un negrero portugués y una comerciante de cautivos en África, Ezili. Esta épica muestra que, además de ser el doble de Henrique el Navegante, Nagó es el doble de otro fundador violento. Este colonizador implica a España, Portugal y toda Europa en la violencia simbiótica de la esclavitud, la colonización de América y el desarrollo de Occidente: Cristóbal Colón (1451-1506). En la edición de 2010 de la novela, el Conquistador original no aparece en la primera sección de la epopeya "Orígenes", llamada "La tierra de los ancestros" (41), donde los invasores europeos son animalizados como la Loba Blanca. En Changó (2010), Colón aparece por primera vez en los versos intercalados en la prosa de la sección "La trata" (89):

\author{
Changó el tallador de los fuegos \\ escogió entre tótems su modelo: \\ serpiente burladora de trampas \\ movimientos rápidos de ardilla. \\ Su pecho coraza de rinoceronte \\ potente su mandíbula, garra de león. \\ Desde el vientre de su madre \\ escuchó los relatos de su abuelo, \\ extraños viajes en aguas uterinas \\ por navegantes olmecas recorridas. \\ Consejero fue de Colombo \\ esclavo y práctico de bitácora. (2010: 89-90)
}

En ambas versiones, las de Tennessee y las de Changó, Nagó es consejero de Colombo (Colón). Mientras Nagó no capitanea la Santa María de Colón, sino un barco negrero, el papel de "consejero de Colombo" es una leyenda significativa. Lo que sí se sabe es que Colón exploró África antes de embarcar para el Nuevo Mundo, una realidad que Zapata Olivella desarrolla de manera decolonial en la obra - la opresión de los indígenas comienza y ocurre al lado de la esclavización de los negros como parte del mismo proceso de colonización violenta (Hair, 1990: 113; Charles, 1995, p. 134). Para cambiar el "centro del mundo" en la novela, la Conquista no comienza con Colón sino con los mitos africanos, con el muntu (hombre) que se desarrolla a partir de África, no de Europa (Zapata Olivella, 2010: 648). Por eso, el canto que pone a Nagó no solo a la altura de, sino también al lado de Colón, ocurre en el contexto de los puertos de la Costa de Esclavos. Además, para enraizar la Conquista en África aún más, Zapata Olivella alude a la teoría de Ivan van Sertima en They came before Columbus (2003) que sostiene que marineros africanos, antecedentes de los olmecas, habían descubierto América antes de Colón. Por sus actos y por su linaje, Nagó es más 
que el "consejero de Colón": transciende la muerte y el sufrimiento de la esclavitud para refundar el Nuevo Mundo como una lucha por la liberación de la humanidad. Por eso Nagó lleva armas y tótems africanos (rinocerontes, leones) para protegerlo y ayudarlo en sus batallas.

Además, el poema que alude a Colón se presenta en la novela (2010) como la épica que la vieja africana esclavizada Arún canta a la negrera africana Ezili en Mali. Ella se la canta a su ama en un ritual de sanación con hierbas (2010: 87). Es probable que este canto sea la inspiración para la rebeldía final de Ezili cuando mata al negrero portugués Egas Muñís y se suicida. El arma asesina es el veneno de la anciana (107). Este canto, al descontextualizarse de los demás de "La tierra de los ancestros" y recontextualizarse en la prosa de "La trata", forma parte de un momento de rebelión anticolonial. Es el canto que convence a la villana Ezili, la que tiene nombre de una loa de la religión vudú relacionada con Yemayá y Ochún, de que aliarse a los opresores ya no es su destino (Dayan, 1994, p. 11).

La serie de poemas "Consagración de Nagó" hallada en Vanderbilt ejemplifica los dos lados de Arún y, de manera más extravagante, de Nagó el Navegante: el del poeta y el de la violencia física. Al final del poema 102, ${ }^{3}$ leemos el canto del poeta Bandama, llamado Ngafúa en la versión final:

¡Por voluntad de los Ancestros
esta noche te consagro!
Abre los brazos
quédate inmóvil en el ritmo
que la vertical de tu cuerpo
sobre tus brazos abiertos
sea la cruz de Elegba
vida y sombra de nuestro pueblo
en el país desconocido.
La cruz, símbolo que te nombra
será tu palabra, tu lanza y tu sombra.
Levanta la tenaza del herrero
forjada en las fraguas de Ogún
y crúzala sobre tu lanza cazadora

La tradición hispánica ya incluía la tradición de la combinación de las armas y las letras, protagonizada por nadie menos que Miguel de Cervantes Saavedra en El Quijote, ya que El Manco de Lepanto perdió su brazo en la guerra antes de contemplar la vida a través de la novela (Moner, 2019). Sin embargo, Zapata Olivella está utilizando este debate para celebrar los aportes africanos a Latinoamérica.

\footnotetext{
${ }^{3}$ Cada alusión a un poema numerado se refiere a los textos de Vanderbilt (poemas 23-24, 45-46, 68, 99, 102-04).
} 
La lanza viene del herrero Ogún, por ejemplo. En la versión final de la novela, la lanza viene del mensajero de los dioses, Elegba, el que se dirige a Nagó:

Toma mi sonaja de fuego: nadie encerrará tu inteligencia.

Toma el puñado de los vientos: nadie encerrará tu espíritu.

Toma la lanza y el escudo de Orún: será poderoso por la fuerza de tu puño. (Zapata Olivella, 2010: 91-92)

Según Santos, “Así, fuego y viento están conectados con la presencia del escudo de Orum [sic], mientras que el devenir apunta hacia el hijo del muntu, que en la novela es metáfora de grandes personajes que incorporarán el deseo de liberación o, más bien, de humanidad" (2016: 31). Santos define "Orum" como "Oricha del sol” (2016: 31) y el personaje aparece varias veces en la novela bajo el nombre "Orún” (Zapata Olivella, 2010: 56). En la versión de 2010 de "Orígenes”, su escudo es el sol (56). Orún es el destino de la libertad de la diáspora que la loba blanca, los colonizadores blancos robaron (107). Además, es un oricha de la ira que aparece durante los funerales de Malcolm X cuando un baobab brota de su cuerpo al final de la novela (644). Al principio de la misma, durante los poemas de "Los orígenes", cuando Orún otorga sus armas a Nagó, su ira es justa y necesaria. Es la furia que la diáspora necesita para poder luchar continuamente contra su opresión bajo la esclavitud y el racismo del Nuevo Mundo. El subtítulo de las memorias de Zapata Olivella sobre su viaje por Estados Unidos durante la época de la segregación racial, He visto la noche, es "Las raíces de la furia negra" (1969). Sin embargo, esa furia, la de la rebelión armada, se apaga cuando Malcolm X se convierte en el árbol sagrado de muchos pueblos africanos, el baobab. Changó, el dios justiciero aparece, igualmente furioso. Su furia no es contra Malcolm X ni los antepasados rebeldes como Nagó, sino contra los lectores que no se han liberado todavía de ese pasado de colonialismo y racismo (2010: 645). Elegba controla a los orichas, pero critica a los lectores por su pasividad. Por lo tanto, la lanza de Orún que protege a Nagó es regalo de Elegba, no de Ogún, lo que implica que es la furia misma, representada por los ojos rojos de Orún y el sol rojo, lo que logrará la victoria de los negros sobre sus opresores. En la versión de los papeles de Nashville, la salvación vendrá de la memoria de África, tema que también está presente en la novela, pero siempre en la forma del muntu. Como el muntu es el hombre y todo lo que lo rodea, podemos ver la lanza de Orún, empoderada por "la fuerza de tu puño" (y no simplemente una fuerza natural) en la versión final, como una afirmación de la agencia de los vivos de este mundo y no solamente la memoria de África en la forma de los animales y los antepasados.

La lanza de Nagó se relaciona con la cruz, tanto en las obras halladas en Tennessee como en la versión de 2010 de la novela: "La cruz, símbolo que te nombra / será tu palabra, tu lanza y tu sombra" (102). Por lo tanto, las palabras son tan poderosas y pueden ser tan violentas como la lanza de la guerra. La cruz es, desde luego, el símbolo universal del cristianismo. La Iglesia Católica justificó la esclavitud y el colonialismo tanto en África como en América. Parte del proceso de esclavización era bautizar a los esclavos con nombres cristianos y comenzar, en distintos momentos 
y a distintos niveles, su aculturación a través del lenguaje. Sin embargo, Zapata Olivella está subvirtiendo esta tradición como los mismos africanos lo hicieron con sus religiones ancestrales. La Cruz de Elegba o Legua es el símbolo que une el mundo profano con el mundo espiritual usando los poderes de la deidad yoruba. Por supuesto, una interpretación cristiana de resurrección después de la tortura y la muerte tampoco excluye el sincretismo claro del texto. El renacimiento es un motivo de la obra. La Cruz de Elegua es, en el texto, una reinscripción del cuerpo negro no como objeto para ser explotado sino como un lugar sagrado. Es un cuerpo activo que está alejado de sus orígenes como la diáspora africana.

La Cruz de Elegua une a Nagó tanto al guerrero Changó como a Elegua, el que se define a través de las paradojas. Según Santos, "este oricha tiene su dominio sobre las encrucijadas, dispone de una personalidad llena de paradojas. Es joven y viejo, alto y bajo, con una naturaleza lujuriosa [. . .]. Exu [Elegua] siembra el conflicto, y con su habilidad sabe armonizar lo que él mismo causó" (2016: 36). En "Ngafúa presenta a Nagó el Navegante", poema de la biblioteca Heard, leemos las paradojas que Nagó personifica:

(Linga incansable

recoge tu voz eco

las preguntas sin respuestas

las voces ahogadas en el río

las palabras perdidas en las cuevas ${ }^{4}$

El linga es un tambor de madera que se utiliza para comunicar mensajes a larga distancia (Zapata Olivella, 2010a: 657). Este instrumento es una metonimia para la poesía misma, personificada por un ser humano incansable que transciende los mundos de los vivos y los muertos.

A través de figuras como el griot Ngafúa y el guerrero-poeta Nagó, Zapata Olivella realiza un arte poético. Como Horacio en El Arte Poética, cuando el novelista-poeta describe a Ngafúa o a Nagó, está escribiendo meta-poesía y meta-historia. La Poética de Aristóteles nos ha brindado una diferencia clara entre el poeta, el creador literario, y el historiador, funciones que están en tensión en la obra de Zapata Olivella:

De lo que hemos dicho se desprende que la tarea del poeta es describir no lo que ha acontecido, sino lo que podría haber ocurrido, esto es, tanto lo que es posible como probable o necesario. La distinción entre el historiador y el poeta no consiste en que uno escriba en prosa y el otro en verso; se podrá trasladar al verso la obra de Heródoto, y ella seguiría siendo una clase de historia. La diferencia reside en que uno relata lo que ha sucedido, y el otro lo que podría haber acontecido. (Aristóteles, s.f., IX)

${ }^{4}$ Véase nota 3 . 
A veces el papel de rapsoda, a diferencia del historiador seguidor de Heródoto, es imaginar las voces perdidas de la historia. Las "voces eco" en "Ngafúa presenta a Nagó" son un resultado sin causa, una mise en abîme. Comunica la historia de la gente sin voz usando los versos del poeta y los dioses que los esclavizados conocían.

En estos textos la forja de Ogún se opone a la de Changó. Los tótems africanos - la serpiente, la ardilla, el león - también vienen de Ogún en el poema 45. Como armas, las fuerzas vitales de estos animales pasan al héroe épico Nagó para combatir a la vil Loba Blanca, los esclavizadores. Sin embargo, en la versión final, los tótems vienen de Changó (2010: 89). Ogún es África, Changó es la esclavitud, ya que los ancestros africanos y sus descendientes son

milenarios sabios de otros mundos

en la América violada por la Loba

cárcel vil, forja de Changó

para templar el muntu. ${ }^{5}$

Para salir de esta prisión, el muntu, la diáspora africana, necesita la fuerza de sus tradiciones en su continente de origen. Fomenta una revolución inspirada por los espíritus africanos, no un regreso a un origen perdido. Esta lucha ya es compleja, así que parece que el autor borró a Ogún para simplificar el argumento.

En la misma estrofa, comienzan paradojas que expresan sinestesia en el texto 46, una especie de súper-poder que Nagó posee al igual que las armas africanas y un regalo de Elegua, el semidios de las paradojas (2016: 36$)$ :

encendieron las palabras

para que entre ekobios desterrados

los temores borrara [sic] con su voz

la esperanza sembrara con su sombra.

Fue Legba el sagrado dibujante

quien trazó la planta de su pie

alargada huella entre dos mundos,

ala ágil de los barcos navegantes

brújula de quillas y abridor de rumbos.

Y para señal de ciegos, mudos y sordos

el símbolo mágico de las dos serpientes

visible, nudosas, marcó sobre hombros.

${ }^{5}$ Véase nota 3. 
Escuchemos su memoria relato

lo que vieron sus ojos en dormidos espejos ${ }^{6}$

La voz del valiente Nagó “borra” los temores de la diáspora durante su lucha contra la opresión. Es un sonido que escribe y reinscribe. Los barcos negreros, bajo influencia de Nagó, vuelan por el aire y por el tiempo a causa de su fuerza mágica. Legba le da una señal al marinero para los que no pueden tener ciertas sensaciones en este mundo - ciegos, mudos y sordos -: el símbolo mágico de las serpientes, lo que se convierte en marca para todos los héroes de la novela (e.g., Benkos Bioho, Agne Brown). Los ojos ven su propia memoria en el espejo. Sin embargo, es un relato, una fabulación desconectada de su origen, un texto meta-ficcional historiográfico según Antonio Tillis (2001).

La licencia poética permite agencia dentro de la historia para los esclavizados. En el poema 99, la sinestesia es parte de cuando Elegua consagra a Nagó, enfatizada por la anáfora liminal "entre":

entre la muerte y la vida

entre la ceniza y la esperanza

entre el dolor y la risa

entre la alegría y el llanto

por voluntad de los Ancestros

esta noche te consagro! ${ }^{7}$

El dolor y la risa reconocen el trauma de la esclavitud y la resiliencia de la diáspora al lado de la alegría y el llanto. Sin embargo, es un entre-lugar que desafía la imaginación. ¿Qué hay entre las sensaciones de la alegría y el dolor si no la vida misma? En la novela, es ese entre-lugar que une la vida y la muerte donde el pasado muerto puede comunicarse con el presente vivo como en las tradiciones africanas.

La paradoja puede ser una alegoría para la interpretación de la historia. En la poesía 45, la diosa de los ríos Ochún le da a Nagó una visión especial. Sus ojos no ven. Iluminan. No solo reciben información del mundo exterior. Crean luz:

Puso Ochú bajo la hojarasca de sus cejas

los encendidos tizones de sus ojos

que al abrirlos alumbrarán su rostro

hasta con el brillo de una lágrima.

Desatando los nudos de su lengua

en sus labios dormidos los Ancestros ${ }^{8}$

${ }^{6}$ Véase nota 3.

${ }^{7}$ Véase nota 3.

${ }^{8}$ Véase nota 3. 
Una vez más, los ojos proyectan e iluminan el futuro, pero no sin lágrimas sobre el sufrimiento del pasado. Los labios dormidos hablan por una lengua hiperbólicamente silenciada. El autor mismo afirma tal función del poeta-novelista al reescribir la historia en una entrevista sobre Changó: "Yo miro la historia con unos ojos que no son míos. Yo sencillamente miro la historia en su devenir. El devenir de la historia es un permanente renacer, una especie de ave fénix que muere y vuelve a renacer de sus cenizas" (Zapata Olivella, 2001a: 16). La historia desemboca en el futuro, y la función del poeta es, para Zapata Olivella, imaginar ese devenir con ojos que proyectan tanto como reflejan.

La comunión entre los vivos y los muertos ocurre a través de la sinestesia - callar la boca para que los oídos oigan sus propios pensamientos. Habla para escuchar a Elegba - contemplar y crear una manera de quitar los obstáculos en su camino. Durante la consagración de Nagó, Elegua le aconseja:

Cierra la boca,

Los oídos oigan tu pensamiento.

Escucha la palabra de Elegba

en el ritmo invisible de las cosas

solo oyéndolo conocerás el aliento

latente de la vida

que se agita $^{9}$

Esas ideas vienen de lo que escucha en un ritmo invisible, es decir que la expectativa de Nagó es ver ese ritmo, no oírlo. Lo que descubre a través de esta paradoja es la fuerza vital africana, latente, más allá de los cinco sentidos. Esta fuerza se percibe a través del deseo de Elegua:

Tu lengua oiga los sabores
en las aguas diluidas
en los poros y en el grano
en los jugos de las flores
y en la sal de las piedras.
Que tu piel parche de tambor
Sea sensible a la lluvia percutora
...
Y a la palabra trueno de la nube. ${ }^{10}$

La lengua oye sabores. La piel siente palabras de la naturaleza. El sujeto afrodescendiente, en comunión con la naturaleza, tiene que experimentar lo extrasensorial. Nagó es ese modelo.

\footnotetext{
${ }^{9}$ Véase nota 3
}

${ }^{10}$ Véase nota 3. 
En los textos 102 y 103, Nagó hace lo imposible una vez más a mando de Elegua:

Solo viendo los invisibles sonidos

descubrirás los mensajes escondidos.

Tu corazón

103

permanente llamarada

alegrará la rebelde sonrisa del ahorcado

y la lágrima de la madre

que deje embarazada. ${ }^{11}$

Nagó ve sonidos que son invisibles para los demás. Como sus ojos, su corazón no siente las emociones o las sensaciones, sino que las da a otros. En este caso son las víctimas de los linchamientos durante y después de la esclavitud. Este pasado brutal nos hace desear un futuro mejor.

El oricha Changó no puede ver el futuro. Solo el que tiene las tablas de Ifá donde todo está escrito puede verlo según la cosmovisión animista de la novela (Zapata Olivella, 2010a: 59). Nagó, en estos poemas, también puede ver el devenir, así que en ese sentido es más hijo de Elegua que de Changó. Elegua se explica en el texto 103:

¡É́a Nagó hijo de Jalunga

biznieto de Sassandra!

Caminante sin reposo

los Orichas te dejan mirar

la cristalina fuente del futuro

el porvenir que corre hacia tu encuentro

desde el más remoto confín hasta tus ojos.

Habitante de otros cuerpos

sembrarás el sol en sus noches

sabiduría en las palabras

fuego en la ceniza

vida en la muerte

risa en el dolor ${ }^{12}$

Nagó llega al extremo de sentir con otros cuerpos y encontrar risa en el dolor. Esa sinestesia crea sabiduría, porque crea poesía, o sea "belleza en la fealdad / y constancia en el dolor” (poema 104). La poesía crea fuerza a través de la resiliencia.

\footnotetext{
${ }^{11}$ Véase nota 3.

${ }^{12}$ Véase nota 3.
} 
Mi interpretación de Nagó como poeta también se apoya en la estrofa final del número 104:

Protegido de [Tachado: Elegba. Escrito a mano: Changó]

caminante sin retorno

presente memoria

pasada experiencia

vivo recuerdo de los sabios

verbo creador

la vida sale

al golpe de tus labios. ${ }^{13}$

Nagó puede experimentar lo que parece imposible sentir. Puede poner en palabras y actos lo que los demás no pueden si solo piensan en términos concretos. Está en contacto con los espíritus africanos y la historia de la opresión por un lado y el presente y el verbo creador de la poesía por otro. Inmediatamente después de la consagración del poeta-guerrero Nagó, el rapsoda Bandama despide a los artesanos. En la obra 23, Bandama les canta:
Alejaos tranquilos
el cuerpo desnudo
sin tambores de guerra
quebrada la lanza
perdido el escudo
y la frente descubierta.

Solo el pasado en tu memoria

la imperdible huella de los sabios. ${ }^{14}$

Como los artesanos africanos pierden todo lo material que tenían en África, ellos tienen que depender de lo espiritual, la poesía, para aguantar la opresión en América. No olvidemos que la forja de Ogún también es una artesanía. En él, el binarismo occidental de las armas y las letras se deshace: el guerrero, el herrero y el artista son uno. La poesía es el arma más fuerte de la diáspora, porque mira hacia el pasado para re-imaginar el futuro porque puede ver lo que todavía no existe. Y, como afirma el poema 24, el griot Bandama ordena a los artesanos "conquistadores sin bandera / separaos de vuestros amos" - diciéndoles que no tienen más nación que la diáspora y hay que combatir la opresión.

Nagó es guerrero-poeta e hijo de Changó en los documentos hallados en la biblioteca Heard, pero necesita la fuerza creativa de Oko, el hermano de Changó. En la versión final, Changó echa al

\footnotetext{
${ }^{13}$ Véase nota 3.

${ }^{14}$ Véase nota 3.
} 
poeta de África. Como afirma Santos, el griot guarda y cuenta la memoria colectiva en muchas sociedades africanas (2016: 37). La pérdida del griot Oko hace que el muntu, la diáspora, se olvide de sus raíces culturales e históricas, ya que no tenían documentación escrita:

y hasta al dulce Oko

el músico, el poeta

que fertiliza la tierra con su gracia

las flautas, la kora, las trompetas

para danzar con ellas, arrebató. (2010: 56)

El nombre de Oko se menciona en una sola ocasión después de su expulsión y en la misma sección de la novela "Los orígenes":

¡Oko tiéndenos tu mano!

Señor de la siembra y la cosecha

danos el ñame y la palmera

la olorosa almáciga

el blando dedo de los plátanos.

Aquí te invoco

para que nutras la espiga de millo

nacida en la pradera

a la orilla de los ríos y de la mar.

¡Hijos son,

hijos de Yemayá! (2010: 53)

O sea, la fertilidad de la poesía es la misma que crea la fecundidad de la naturaleza en la cosmovisión del muntu en la novela.

El fértil Oko tiene sus propios poemas en Vanderbilt. Uno, el número 68, aparece al final de una sección que parece haber pasado por varios títulos debido a cambios hechos a mano: "Título: Sombras Que Tenéis la Suerte de Conversar con los Orichas" aparece con una flecha señalando "Ancestros / sombras de mis mayores; [tachado]: Invocación a los [a mano: sus] Ancestros; [a mano] "Bandama, el poeta; [siguiente verso:] Canto Épico, Invoca." Los títulos parecen confusos, pero queda claro que Oko y Bandama siguen cumpliendo el papel de poeta al lado del poeta-guerrero Nagó en las obras inéditas. El poema 68 reaparece en la novela como "Sombras de mis mayores" (2010: 45-46). Aludiendo a Oko, Bandma canta:

Hoy enterramos el mijo

la semilla sagrada

en lo profundo de la tierra

en el ombligo de la madre África

para que muera

se pudra en su seno 
y en la sangre renazca en América.

64

(¡Dame ese canto

alto

alto

alto

oko-linga

para subir al cielo

oko-linga

y soltar la pena

que camina por dentro! $)^{15}$

Como en la tradición europea, el poeta es músico. Sin embargo, además de arpista, el poeta africano es baterista.

Oko reaparece en los poemas previamente desconocidos como el número 6 de una serie en orden numérico que se llama "Instrumentos" y que lleva una nota descriptiva que dice "Descripción de iniciación”. Estos instrumentos serían los de una ceremonia afro-diaspórica para comenzar la novela. Hay guiones en los archivos para cine y televisión. Además de estos géneros, Zapata Olivella hacía espectáculos folclóricos afro-colombianos con su hermana Delia que incluían performances de baile (Sandoval, 2015). Quizá los poemas describen su visión para una puesta en escena de la novela. La serie de poemas incluye el linga, la kora, el violín, el iyo ilu y la marimba, todos instrumentos africanos menos el violín.

En "Oko Linga”, el instrumento mismo es la musa africana del poeta:

Dame ese canto

alto, alto, alto

Oko Linga

para subir al cielo

Oko-Linga

y soltar la pena

Oko-Linga

que camina por dentro.

Duro el golpe

duro el golpe

${ }^{15}$ Véase nota 3. 
Oko-linga
que resuene
que estalle
o que reviente
la piel que me envuelve. ${ }^{16}$

Oko, el poeta, es parte del espíritu de la música popular. Oko y Nagó son los espíritus del muntu africano y atlántico-americano, respectivamente.

Si, en la versión final de la novela, la de 1983, Nagó ya no es el poeta-guerrero que era en los poemas de Tennessee, ¿quién es ese poeta? ¿Será que Zapata Olivella resolvió el debate de las armas y las letras y optó por violencia filistea? No. Su estética es plenamente vanguardista debido a neologismos como rostromañana (2010: 71), Machocabrío-Changó-sol (138), ayermañana (146), términos extranjeros resignificados como ekobio (230), muntu (230) y tata (428), y el uso de la antropología y culturas no-occidentales como inspiración poética. Loa rebeliones armadas. Utiliza un marco teórico marxista, otro rasgo común de la vanguardia. En este contexto, el cambio del nombre del narrador-poeta de Bandama a Ngafúa indica su admiración por un poeta en particular. En las obras de la biblioteca Heard, el griot que invoca los espíritus y al público al principio de la serie de textos lleva el nombre de Bandama. El de la versión definitiva (1983) es Ngafúa. Changó ejemplifica una atención obsesiva por parte del autor a la dicción, así que el cambio no es caprichoso. Como se ve en el interfolio de este número especial de Visitas al Patio, varios títulos aluden a Bandama: "Presentación de Nagó a Bandama" o "La Alargada Huella Entre Dos Mundos" (poema 48) y "Bandama despide a los artesanos" (poema 23). El segundo título, "La Alargada Huella", corresponde a la tercera sección de "Los orígenes" en la que el motín de Nagó el Navegante triunfa y el muntu (la diáspora) naufraga en el Nuevo Mundo (2010: 108). Incluyo aquí notas de los textos de Nashville que confirman que Bandama es rapsoda: "poema \# 66 [a mano, dos hojas grapadas; primera hoja: “Título: Sombras Que Tenéis la Suerte de Conversar con los Orichas” con una flecha señalando el nuevo título "Ancestros / sombras de mis mayores; a mano, tachado: Invocación a los [a mano: sus] Ancestros; a mano: Bandama, el poeta; próxima línea: Canto Épico, Invoca]. Queda claro que Bandama es Ngafúa en la versión de los papeles del autor.

Bandama es el poeta creador, aunque Nagó el Navegante también es el elegido de Changó y Elegua. Bandama está recreando la memoria colectiva. Su nombre en sí es un acto de recordación. Alude al río más grande de la Costa de Marfil, al igual que el río Sassandra, el abuelo de Nagó (poema 102, "Consagración de Nagó”). ${ }^{17}$ Los pueblos kru y grebo habitan esa región de la Costa de

\footnotetext{
${ }^{16}$ Véase nota 3.

${ }^{17}$ Jalunga, o yalunka, se refiere a un grupo lingüístico africano (Taylor 2014, p. 154).
} 
Marfil, Liberia y Sierra Leona. Algunos de ellos contaban entre los primeros pueblos que los portugueses encontraron en el continente africano en el siglo XV (Ogot, 1992: 374). Otros son los que por más tiempo resistieron la invasión y la esclavitud. De hecho, las marcas rituales que ponían en sus cuerpos representaban su libertad y resistencia sempiterna desde la época de la esclavitud hasta el siglo XX (Biyi, 1929: 72). Las serpientes de Elegua son una adaptación poética de este tipo de marca, un doble libertario a las marcas de la opresión de la esclavitud como la carimba y el queloide. Además, los kru son un grupo sumamente diverso. De hecho, no se puede decir que una etnia "kru" o una etnia "grebo" unida existía hasta que varios miembros de los grupos se encontraron en una diáspora como el muntu en la novela de Zapata Olivella (McEvoy, 1977: 67-68). Los grebos también vivieron aislados de la esclavitud, la colonización y la modernidad (Meneghini, 1974: 36). Adoptaron su nombre debido a su escape legendario de la esclavitud (37). Habían habitado la margen del río Cavalla, pero rivales africanos invadieron la región buscando cautivos. Aunque los grebos no conocían las embarcaciones, rápidamente construyeron o robaron canoas para poder huir. Para esta gente que desconocía la costa atlántica, los ancestros flotando en las olas del mar (o el río) parecían monos columpiándose entre los árboles o, en su lengua gle "mono rápido que se columpia" bo "pueblo" (Meghini, 1974: 37). Como afirma el poema 44 de Nashville y la página 123 de Changó (2010), Nagó el Navegante es “biznieto de Sassandra, el Grebo”. El guerrero marítimo es descendiente de los pueblos no-colonizados de África. El poeta Bandama también es hijo de un pasado que resiste la esclavitud y las distorsiones históricas de los pueblos africanos. Si Bandama tiene nombre de los pueblos rebeldes y diaspóricos al igual que el protagonista elegido por Changó, ¿por qué cambiar su nombre?

Zapata Olivella ve en la poesía la posibilidad de superar el pasado porque lo transciende. Ngafúa es el apellido del poeta Zizwe Omowale-Wa-Ngafúa (s/f.). Según Éric Jolly (2014: 51), Ngafúa era un poeta radical que escribió durante los años setenta. En su ambiente, revistas afroamericanas radicales se apropiaron de los conceptos del muntu y del nommo. Ambos conceptos fueron popularizados por Janheinz Jahn (1918-1973), que conocía la obra de Léopold Senghor y Aimé Césaire por haber sido su traductor (Jolly, 2014: 51). Como los poetas de la negritud, Jahn buscaba una fuente autóctona de cultura panafricana y la encontró en el nommo, que era un genio fluvial de los dogón de Mali (51). El "séptimo genio" era la Madre del Habla, la que creaba cosas con sus palabras (51). Para los revolucionarios afro-céntricos, el nommo se convirtió en la fuerza panafricana de liberarse a través de la palabra, incluso la palabra escrita de los negros en las Américas. Ngafúa escribió un poemario que alude a esta fuerza: "Dans le livre de poésies Nom Nomm Nommo, publié en 1978, Zizwe Omowale-Wa-Ngafúa affirme en introduction la volonté des artistes noirs de construire à travers leur oeuvre une contre-culture opposée à l'oppression et tournée vers l'Afrique"18 (Jolly, 2014: 52). Es probable que Zapata Olivella, que había vivido en Nueva York, conociera las obras de poetas nuyoriqueños como Louis Reyes Rivera, editor del

\footnotetext{
18 “En el libro de poesías Nom Nomm Nommo, publicado en 1978, Zizwe Omowale-Wa-Ngafúa afirma en la introducción la voluntad de los artistas negros de construir a través de su obra una contracultura opositora a la opresión y dirigida hacia África"
} 
poemario de Ngafúa (Medina, 2012: s/p.). Zapata Olivella conocía la obra de Jahn y se inspira en él para crear su visión del muntu en que el hombre viene de África y tiene contacto psíquico con la naturaleza y sus antepasados (Sierra Díaz, 2016: 26).

La alusión a Ngafúa es la afirmación de que el negro puede recrear el mundo a través del lenguaje poético. La letra, el nommo, es el arma más poderosa del negro, como la novela muestra. El nommo es más importante que un pasado imaginario de un África impoluta anterior a la esclavitud. La palabra es más fuerte porque crea un futuro que transciende la opresión sin olvidarla.

Zapata Olivella interviene en la historia de los casos de Henrique el Navegante y Cristóbal Colón a través de la contra-narrativa del guerrero Nagó. No obstante, los textos descubiertos en Nashville muestran que Nagó tenía otras formas de agencia: la sinestesia y la paradoja, las que vienen de Elegua. Las armas del guerrero tienen su propia poética. Además, este tiene la ayuda de Oko en las versiones previas de los poemas. Su evolución es complementada por la de Bandama, que se convierte en Ngafúa para reafirmar el papel libertador de la poesía.

\section{BIBLIOGRAFÍA}

Aristóteles. s/f. La poética. Granada: Universidad de Granada. Recuperado de https://www.ugr. es/ encinas/Docencia/Aristoteles_Poetica.pdf

Biyi, E. (1929). The Kru and Related Peoples. Journal of the Royal African Society, 29(113), 71-77.

Cabral, C. (2001). Changó, el gran Putas: El afrocentrismo estructural y temático de "Los Orígenes". Afro-Hispanic Review, 20(1), 79-89.

Captain-Hidalgo, Y. (1993). The Culture of Fiction in the Works of Manuel Zapata Olivella. Columbia: University of Missouri Press.

Charles, A. (1995). Colonial Discourse since Christopher Columbus. Journal of Black Studies, 26(2), 134-52.

Cuervo-Hewitt, J. (2003). Luís de Camoens en el reino de Calibán: Las “Lusíadas” en “Changó, el Gran Putas” de Manuel Zapata Olivella. Afro-Hispanic Review, 22(1), 13-23.

Dayan, J. (1994). Erzulie: A Women's History of Haiti. Research in African Literatures, 25(2), 5-31.

Gómez, P. (2011). La colección de Manuel Zapata Olivella. Revista de Estudios Colombianos, $37-38,117-18$. 
Hair, P.E.H. (1990). Columbus from Guinea to America. History in Africa, 17, 113-29.

Horacio. (1777). El arte poética. Madrid: Biblioteca Nacional de España. Recuperado de http:// bdh.bne.es/bnesearch/detalle/bdh0000094626

Janis, M. (2005). Negritude, Mestizaje, Africana Philosophy: Zapata Olivella and Multiculturalist Pan-Africanism. Présence Africaine, Nouvelle Série, (171), 69-79.

Jolly, E. (2014). Dogon virtuels et contre-cultures. L'Homme, (211), 41-74.

Luis, W. (2010). Exile and Return in Changó, el gran putas. En: Changó, the Biggest Badass (pp. xiii-xxxv). Lubbock: Texas Tech University Press.

Medina, T. (2012). On the Passing of a Major Revolutionary Poet: Louis Reyes Rivera. En: Shaggy Flores. Nuyorican Negritude: The Official Website. Recuperado de http://www.shaggyflores. com/louis-reyes-rivera-in-memoriam/

McEvoy, F.D. (1977). Understanding Ethnic Realities among the Grebo and Kru Peoples of West Africa. Africa: Journal of the International African Institute, 47(1), 62-80.

Mina Aragón, W. (2006). Manuel Zapata Olivella: Un pensador humanista. Bogotá: Selbstverl.

Ogot, B.A. (1992). General History of Africa. vol. 5. Africa from the Sixteenth to the EighteenthCentury. Nueva York: United Nations Educational, Scientific, and Cultural Organization.

Sandoval, S.A. (2015). Las herencias del Muntu: arte y libertad en Manuel Zapata Olivella. En: Manuel Zapata Olivella: Un legado intercultural (pp. 255-66). Popayán: Editorial Universidad del Cauca.

Santafé Valcárcel, E. (2017). La epopeya libertaria de los ancestros. Religión, historia y memoria en Changó, el gran putas de Manuel Zapata Olivella. Historia y Espacio, (13)48, 277-308.

Santos, D.L. (2016). La recreación de los orikíes en Changó, el gran putas y Sortilégio II. Estudios de Literatura Colombiana, 39, 29-44.

Sertima, I. (2003). They Came before Columbus: The African Presence in Ancient America. Nueva York: Random House. 
Sierra Díaz, D.C. (2016). El Muntu: La diáspora del pensamiento filosófico africano en Changó, el gran putas de Manuel Zapata Olivella. La Palabra 29, 23-44.

Taylor, B.K. (2014). Sierra Leone: The Land, Its People and History. Cape Town: New Africa.

Tillis, A. (2001). Changó, el gran Putas: A Postmodern Historiographic Metafictional Text. Afro-Hispanic Review, 20(1), 96-103.

Valencia Solanilla, C. (2003). Changó, el gran putas: Mito, lenguaje y transgresión. Poligramas, 19, 167-79.

Zapata Olivella, M. (1969). He visto la noche. Las raíces de la furia negra. Medellín: Badout.

Zapata Olivella, M. (1982). El código guerrero. Afro-Hispanic Review, 1(1), s/p.

Zapata Olivella, M. (1982). Navego. Afro-Hispanic Review, 1(1), 16.

Zapata Olivella, M. (1982). Visión: La travesía. Afro-Hispanic Review, 1(1), 16.

Zapata Olivella, M. (2000). Pasión vagabunda. Bogotá: Ministerio de Cultura.

Zapata Olivella, M. (2001a). Conversación informal con Manuel Zapata Olivella, por M. Krakusin. Afro-Hispanic Review, 20(1), 15-28.

Zapata Olivella, M. (2001b). El Muntu en América. Afro-Hispanic Review, 20(1), 13.

Zapata Olivella, M. (2005). El Muntu en América. Guaraguao, 9(20), 69-79.

Zapata Olivella, M. (2010a). Changó, el gran putas. Bogotá: Ministerio de Cultura de Colombia.

Zapata Olivella, M. (2010b). Changó, the Biggest Baddass. Lubbock: Texas Tech University Press.

Zapata Olivella, M. s/f. Poemas inéditos. Vanderbilt University. Heard Library. Manuel Zapata Olivella Papers.

Zoggyie, H. (2001). Lengua e identidad en Changó, el gran Putas de Manuel Zapata Olivella. Afro-Hispanic Review, 20(1), 90-95. 